\title{
Antifungal Activity of Leaf Extracts of Ocimum sanctum against Fungal Pathogens
}

\author{
Satish Sharma*, Reeti Singh and Bhupendra Thakre
}

Department of Plant Pathology, College of Agriculture, R.V.S.K. V.V. Gwalior (M.P), India

*Corresponding author

\begin{abstract}
A B S T R A C T
Keywords

Ocimum sanctum

Leaf extracts,

Fungal pathogens

Article Info

Accepted:

10 March 2019

Available Online:

10 April 2019

Sacred basil (Ocimum sanctum) is contains active ingredients such as alkaloids, enzymes and other inorganic elements. With a view to assess the fungitoxicity of Ocimum sanctum against the fungal pathogens, studies were conducted on the fungitoxicity of Ocimum sanctum against fungal pathogens. It is concluded that all the four forms i.e., crude (10\%), powdered $(10 \%)$, boiled $(10 \%)$ and ethanol $(1 \%)$ extract of Ocimum sanctum leaf significantly inhibited the growth of the test fungus viz., Rhizoctonia solani, R. bataticola, Phoma sorghina, Colletotrichum gloeosporioides, Fusarium oxysporum f.sp. pallidoroseum, F. oxysporum f.sp. ciceri, Sclerotium rolfsii, Sclerotinia sclerotiorum, Alternaria solani and A. alternata, but none of the forms could absolutely inhibited the growth of any one of the test fungus. A concentration of effective form was standardized. The results revealed that all the four forms of Ocimum sanctum leaf extracts significantly inhibited the growth of all above test organisms but none of the forms could absolutely inhibited the growth of any one of the test fungus.
\end{abstract}

\section{Introduction}

Sacred basil (Ocimum sanctum) Syn. Ocimum tenuiflorus known as "Tulsi" is a well known sacred plant of the Hindus, widely used in religious rites since vedic times. In Ayurveda Tulsi is used against all kinds of fevers. Whole plant has antibacterial, antiperiodic, hypotensive and expectorant properties. Ocimum sanctum has also been shown to possess adaptogenic action and leaves of plant show abortifacient and antifertility activities. It lowers blood sugar and increases lactation. Besides its medicinal attributes the plant is valued for its essential oil which is used in antiperspirants and as insect and mosquito repellants.

Besides their therapeutic significance, Ocimum spp. yield essential oils which are valued in perfumery and a few are rich sources of camphor. Essential oil contains a new terpene; seeds contain a large amount of mucilage. Nature has been a source of medicinal agents for thousands of years and an impressive number of modern drugs have been isolated from natural resources. Traditional medicine is an important source of potentially useful new compounds for the development of chemotherapeutic agents. 
Medicinal plants are a source of great economic value all over the world. Nature has bestowed on us a very rich botanical wealth and a large number of diverse types of plants grow in different parts of the country. There is a need to develop alternative antimicrobial drugs for the treatment of infectious diseases from medicinal plants. The conventional synthetic chemicals have raised ecological problems due to their high cost as well as adverse effect on environment and may induce resistance in the pathogen (Rathmell, 1984). Keeping these facts in mind attempts have been made to control this fungus by natural extracts.

\section{Materials and Methods}

The standard laboratory techniques were used for the preparation of media, cleaning of glassware's, isolation, inoculation, sterilization and maintenance of fungal cultures, with modifications whenever necessary. Present investigations were undertaken to study the "Antifungal activity of leaf extracts of Ocimum sanctum against fungal pathogens "With a view to assess the fungitoxicity of Ocimum sanctum against the fungal pathogens, the present study was carried out in the Department of Plant Pathology, College of Agriculture, Gwalior during the year 2011-12. The fungitoxicity of Ocimum sanctum were evaluated against different fungal pathogens under in-vitro condition in the form of extracts. In the present study the fungitoxicity of Ocimum sanctum leaves was evaluated in the form of crude $(10 \%)$, powdered $(10 \%)$, boiled $(10 \%)$ and ethanol $(1 \%)$ extracts against ten fungal pathogens viz., Rhizoctonia solani, $R$. bataticola, Phoma sorghina, Colletotrichum gloeosporioides, Fusarium oxysporium f.sp. pallidoroseum, $F$. oxysporium f.sp. ciceri, Sclerotium rolfsii, Sclerotinia sclerotiorum, Alternaria solani and A. alternate.

\section{Results and Discussion}

The fungitoxicity of Ocimum sanctum leaves was evaluated in the form of powdered (10\%), crude (10\%), boiled (10\%) and ethanol (1\%) extracts against ten fungal pathogens viz., a concentration of effective form was standardize. Their results data presented in Table 1 and Figure 1.

Rhizoctonia solani, $R$. bataticola, Phoma sorghina, Colletotrichum gloeosporioides, Fusarium pallidorosem, $F$. oxysporum (ciceri), Sclerotium rolfsii, Sclerotinia sclerotiorum, Alternaria solani and $A$. alternate efficacy against respectively minimum growth was recorded under its boiled form $(26.67 \mathrm{~mm})$, followed by ethanol $(31.67 \mathrm{~mm})$, crude $(41.67 \mathrm{~mm})$ and powdered $(56.67 \mathrm{~mm})$, while a maximum of 75.00 growth was recorded in control. Boiled form of extract $(10 \%)$ was significantly superior over other forms. Ethanol extract was significantly superior over crude and powdered extract. Boiled extract $(10 \%)$ was least effective but it was at par with ethanol extract. however minimum growth was recorded under its boiled form $(22.50 \mathrm{~mm})$, followed by crude $(35.83 \mathrm{~mm})$, powdered $(55.00 \mathrm{~mm})$ and ethanol extract $(65.00 \mathrm{~mm})$, while the maximum of $80.00 \mathrm{~mm}$ growth was recorded in control. The boil extract was significantly superior over the other forms. The ethanol extract $(1 \%)$. minimum growth was recorded under its crude form (31.67 $\mathrm{mm})$, followed by ethanol extract $(41.67 \mathrm{~mm})$, boiled extract $(45.83 \mathrm{~mm})$ and powdered extract $(51.67 \mathrm{~mm})$, while the maximum of $78.00 \mathrm{~mm}$ growth was recorded in control (Fig. 1). In respect of growth inhibition the crude extract was significantly superior over the other forms except ethanol form. Powdered extract was found the least effective form against the Phoma sorghina. 
The minimum growth of the fungus was recorded under its crude form $(30.00 \mathrm{~mm})$

followed by boiled extract $(33.33 \mathrm{~mm})$, powdered extract $(41.67 \mathrm{~mm})$ and ethanol extract $(45.33 \mathrm{~mm})$, while a maximum growth of $77.00 \mathrm{~mm}$ was recorded in control (Table 1). Crude extract $(10 \%)$ was found most effective and it was significantly superior over other two forms except boiled form. Next to crude, powdered form was found also effective. Crude and boiled extract were at par to each other. minimum growth was recorded under its crude form $(26.67 \mathrm{~mm})$, followed by boiled extract $(31.67 \mathrm{~mm})$, powdered extract $(50.00 \mathrm{~mm})$ and ethanol extract $(51.67 \mathrm{~mm})$, while the maximum of $72.00 \mathrm{~mm}$ growth was recorded in control. minimum growth was recorded under its crude form $(45.00 \mathrm{~mm})$, followed by boiled extract $(55.00 \mathrm{~mm})$, powdered extract $(59.17 \mathrm{~mm})$ and ethanol extract $(61.67 \mathrm{~mm})$, while the maximum of $74.00 \mathrm{~mm}$ growth was recorded in control minimum growth was recorded under its powdered form @ 10\% (35.83 mm) followed by boiled extract @10\% (36.67 mm), ethanol extract@1\% (44.17 mm) and crude extract @ 10\% (46.67 mm), while the maximum of $78.00 \mathrm{~mm}$ growth was recorded in control. The minimum growth was recorded under its powdered form $(21.67 \mathrm{~mm})$, followed by boiled extract $(26.67 \mathrm{~mm})$.

Crude extract $(27.50 \mathrm{~mm})$ and ethanol extract $(35.00 \mathrm{~mm})$, while the maximum of 76.00 $\mathrm{mm}$ growth was recorded in control but it was least effective form against Sclerotinia sclerotiorum. minimum fungal growth $(25.00$ $\mathrm{mm})$ was recorded under its boiled form @ $10 \%$ followed by crude extract $(45.00 \mathrm{~mm})$, ethanol extract $(46.67 \mathrm{~mm})$ and powdered extract $(60.00 \mathrm{~mm})$, while the maximum of $70.00 \mathrm{~mm}$ growth was recorded in control however minimum growth of fungal mycelium $(29.17 \mathrm{~mm})$ was recorded under its boiled form @ 10\%, followed by crude extract@10\%(47.50 mm),powdered extract @ 10\% (51.67 mm) and ethanol extract @ 1\% $(52.50 \mathrm{~mm})$, while the maximum of 72.00 $\mathrm{mm}$ growth was recorded in control.

Table.1 Efficacy of different forms of Ocimum sanctum leaf extracts against fungal pathogens

\begin{tabular}{|c|c|c|c|c|c|c|c|c|c|c|}
\hline \multirow[b]{2}{*}{ Treatments } & \multicolumn{10}{|c|}{$\begin{array}{l}\text { Fungal pathogens } \\
\text { Radial growth (mm) }\end{array}$} \\
\hline & $\begin{array}{c}\text { Rhizoctonia } \\
\text { solani }\end{array}$ & $\begin{array}{l}\text { Rhizoctonia } \\
\text { bataticola }\end{array}$ & $\begin{array}{l}\text { Phoma } \\
\text { sorghina }\end{array}$ & $\begin{array}{l}\text { Colletotrichum } \\
\text { gloeosporioides }\end{array}$ & $\begin{array}{c}\text { F.ox.f.sp. } \\
\text { pallidoroseum }\end{array}$ & $\begin{array}{c}\text { Fusarium } \\
\text { oxysporium } \\
\text { f.sp. ciceri }\end{array}$ & $\begin{array}{l}\text { Sclerotium } \\
\text { rolfsii }\end{array}$ & $\begin{array}{c}\text { Sclerotinia } \\
\text { sclerotiorum }\end{array}$ & $\begin{array}{l}\text { Alternaria } \\
\text { solani }\end{array}$ & $\begin{array}{c}\text { Alternaria } \\
\text { alternata }\end{array}$ \\
\hline $\begin{array}{l}\text { Powdered @ } \\
10 \%\end{array}$ & 56.67 & 55.00 & 51.67 & 41.67 & 50.00 & 59.17 & 35.83 & 21.67 & 60.00 & 51.67 \\
\hline $\begin{array}{l}\text { Crude } \\
\text { @ 10\% }\end{array}$ & 41.67 & 35.83 & 31.67 & 30.00 & 26.67 & 45.00 & 46.67 & 27.50 & 45.00 & 47.50 \\
\hline $\begin{array}{l}\text { Boiled } \\
\text { @ 10\% }\end{array}$ & 26.67 & 22.50 & 45.83 & 33.33 & 31.67 & 55.00 & 36.67 & 26.67 & 25.00 & 29.17 \\
\hline $\begin{array}{l}\text { Ethanol } \\
\text { @ } 1 \%\end{array}$ & 31.67 & 65.00 & 41.67 & 45.33 & 51.67 & 61.67 & 44.17 & 35.00 & 46.67 & 52.50 \\
\hline Control & 75.00 & 80.00 & 78.00 & 77.00 & 72.00 & 74.00 & 78.00 & 76.00 & 70.00 & 72.00 \\
\hline $\begin{array}{l}\text { SE }(m) \pm \\
\text { CD at } 5 \%\end{array}$ & $\begin{array}{c}4.377 \\
13.969\end{array}$ & $\begin{array}{l}2.234 \\
7.129\end{array}$ & $\begin{array}{c}3.592 \\
11.466\end{array}$ & $\begin{array}{c}3.269 \\
10.432\end{array}$ & $\begin{array}{c}3.204 \\
10.227\end{array}$ & $\begin{array}{c}3.151 \\
10.057\end{array}$ & $\begin{array}{l}2.039 \\
6.507\end{array}$ & $\begin{array}{l}2.072 \\
6.614\end{array}$ & $\begin{array}{l}2.413 \\
7.702\end{array}$ & $\begin{array}{l}2.909 \\
9.284\end{array}$ \\
\hline
\end{tabular}


Fig.1 Efficacy of leaf extracts against Radical growth of fungal pathogens

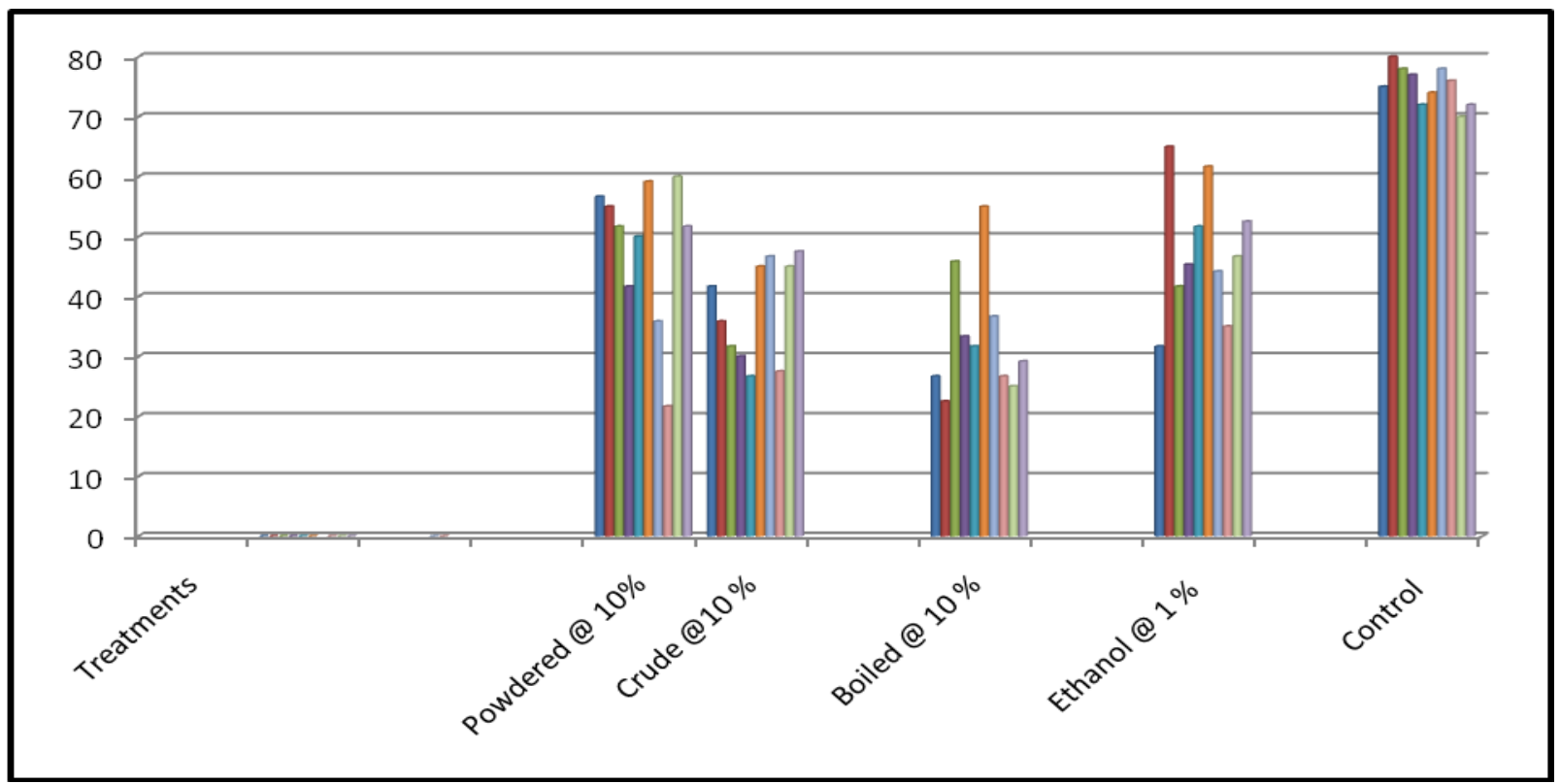

A concentration of effective form was standardized. The results revealed that all the four forms of Ocimum sanctum leaf extracts significantly inhibited the growth of all above test organisms but none of the forms could absolutely inhibited the growth of any one of the test fungus. The boiled extract was found significantly superior over other forms for inhibiting the growth of $R$. solani, Rhizoctonia bataticola, Sclerotium rolfsii, Alternaria solani and A. alternata. This supports the use of boiled Ocimum sanctum leaf extract for the control of these fungi. The growth of the species of Phoma sorghina, Colletotrichum gloeosporioides, Fusarium oxysporum f.sp. ciceri, and Fusarium oxysporium f.sp. pallidoroseum was more effectively inhibited under its crude form than the other four forms, while the powdered form of Ocimum sanctum leaf extract was found more suitable for the control of Sclerotinia sclerotiorum. Jha et al., (2000), Upmanyu and Gupta (2005) and Louis et al., (2011). Upmanu and Gupta (2005).

In conclusion, all the four forms i.e., crude $(10 \%)$, powdered $(10 \%)$, boiled $(10 \%)$ and ethanol (1\%) extract of Ocimum sanctum leaf significantly inhibited the growth of the test fungus, but none of the forms could absolutely inhibited the growth of any one of the test fungus. The boiled extract @ 10\% was found more effective than powdered, crude and ethanol extracts against five fungal pathogens viz. Rhizoctonia solani, $R$. bataticola, Sclerotium rolfsii, Sclerotinia sclerotiorum, Alternaria solani and A. alternata. The effectivity of boiled, crude and powdered extract against the respective fungus was gradually increased with the increase in the concentration from 15 to $20 \%$, but the complete inhibition of the respective test fungus could not achieved even at maximum concentration i.e. $20 \%$.

\section{References}

Adavigowda, S., Gyula, S., Oros, D., Giriyanna, S., Shetty, P., Huntrike, N., Shetty S. and Sheena, S. (2005). Antisporulant activity of leaf extracts of Indian plants against Sclerospora graminicola causing downy mildew disease of pearl millet. Archi, Phytopath 
and Pl. Protect., 38(1): 31-39.

Anamika and Simon, Sobita (2011). Inhibitory effect of botanical extracts against Alternaria alternata of Aloe vera dry rot. Archives of Phytopath. and Pl. Protect., 44(15): 1462-1466.

Bagwan, N.B. (2001). Anthracnose of banana fruits and its management with plant extracts. Current Research University of Agricultural Sciences Bangalore, 30(11\&12): 197-198.

Bansal, R.K. and Gupta, R.K. (2000). Evaluation of plant extracts against Fusarium oxysporum, wilt pathogen of fenugreek. Indian Phytopathology, 53(1): 107-108.

Chohan, Sobia, Atiq, Rashida, Mehmood, M.A., Naz, Safina and Haider, Saleem (2011). Efficacy of few plant extracts against Fusarium oxysporum f.sp. gladioli, the cause of corm rot of gladiolus. J. Medic. Pl. Res., 5(16): 3887-3890.

Damayanti, M., Susheela, K. and Sharma, G.J. (1996). Effect of plant extracts and systemic fungicide on the pineapple fruit-rotting fungus, Ceratocystis paradoxa. Cytobios, 86(346): 155-165.

Dwivedi, B.P. and Shukla, D.N. (2000). Effect of leaf extracts of some medicinal plants on spore germination of some Fusarium species. Karnataka J. Agric. Sci., 13(1): 153-154.

Gupta, R.K. and Bansal, R.K. (2003). Comparative efficacy of plant leaf extracts and fungicides against $F$. oxysporum Schlecht inducing fenugreek wilt under pot house condition. Annals
Biol., 19(1): 35-37.

Kurucheve, V., Ezhilan, J.G. and Jayaraj, J. (1997). Screening of higher plants for fungitoxicity against Rhizoctonia solani in-vitro. Indian Phytopath., 50(2): 235241.

Lakpale, N., Khare, N. and Thrimurty, V.S. (2008). Evaluation of botanicals for antimicrobial properties. J. Mycol. Pathol. Res., 38(3): 614-617.

Murugesan, Subban, Ramasamy, Vijayakumar and Panneerselvam, Annamalai (2011). Antifungal activity of medicinal plants against plant pathogenic fungus Fusarium oxysporum. J. Pharmacy Res., 4(3): 843-844.

Shivpuri, Asha and Gupta, R.B.L. (2001). Evaluation of different fungicides and plant extracts against Sclerotinia sclerotiorum causing stem rot of mustard. Indian Phytopath., 54(2): 272274.

Singh, Jitendra and Mazumdar, V. (2001). Efficacy of plant extracts against Fusarium solani incident of soybean, pomegranate (Puccina granatum L.). J. Mycol. Pl. Path., 31(3): 384-386.

Sinha, A.K., Verma, K.P., Agrawal, K.C. and Thakur, M.P. (2002). Antifungal activities of different plant extracts against Colletotrichum capsici. J. Mycol. Pl. Pathol., 32(2): 267.

Tripathi, M.N., Shukla, D.N. and Dwivedi, B.K. (1999). Effect of aqueous extracts of leaves of some medicinal plants on spore germination of Fusarium spp. Bioved, 10(1\&2): 43-44.

\section{How to cite this article:}

Satish Sharma, Reeti Singh and Bhupendra Thakre. 2019. Antifungal Activity of Leaf Extracts of Ocimum sanctum against Fungal Pathogens. Int.J.Curr.Microbiol.App.Sci. 8(04): 12101214. doi: https://doi.org/10.20546/ijcmas.2019.804.139 